\title{
Drinking of tap water is smart, but how do it better? \\ - A tap water quality research
}

\author{
Anna Mika ${ }^{1 *}$, Klaudia Sekuła ${ }^{1}$, Marta Dendys $^{2}$, Weronika Ptaszek $^{1}$, Adam Postawa $^{1}$ \\ ${ }^{1}$ Department of Hydrogeology and Geology Engineering, AGH University of Science and \\ Technology, Av. Mickiewicza 30, 30-059 Krakow \\ ${ }^{2}$ Mineral and Energy Economy Research Institute, Polish Academy of Sciences, Wybickiego 7 St., \\ 31-261 Krakow
}

\begin{abstract}
Drinking tap water has recently become popular. It is a way to fight with the tons of garbage (disposable, plastic bottles). However, many people are afraid of water quality. The research was performed in December 2015 in Krakow, during one week. 56 samples were collected. The samples were taken in different times of the day and in the two types of building (old one with installation from the 80s and new one with installation built in past few years). Samples were taken by two qualified operators. The first sample was collected at the morning at 6 a.m., before anyone uses the tap. The second one after the tap was flushed and then the third one after 30 minutes stagnation. At the evening was taken one sample (after using the tap all day).The aim of the research was to check the quality of drinking water in the end-user. The results show that quality of tap water in Krakow is good, also in the end-user, but the concentration of chemical elements are changing during the flushing and using of the tap.
\end{abstract}

\section{THE QUALITY OF DRINKING WATER IN POLAND}

Drinking water in Poland must fulfil the requirements of Drinking Water Directive from 3 November 1998 (and Commission Directive (EU) 2015/1787 of 6 October 2015 amending Annexes II and III to Council Directive 98/83/EC) [1] and also Regulation of Polish Minister of Health of 13 November 2015 on the scope on the quality of water intended for human consumption [2]. The specified parametric values for selected components should not be exceeded both at the initial point of water distribution as well as in the end-user. Many factors related to the water supply network and inner installation in the building influence on the concentration of chemical elements in water [3]. However, water supply companies are not obligated to analyse the water in the end-user. The companies haven't got any influence on the condition of pipe system in the buildings.

\subsection{The quality of water in Krakow}

The water in Krakow fulfils all the requirements. The quality of water is analysed regularly by Krakow Waterworks Laboratory. The map of the water supply system is available on company website. It is possible to check from which treatment plant is the water

${ }^{*}$ Corresponding author: annamika@agh.edu.pl 
supplying in concrete district. The chemical composition of water (from all treatment plants for actually period) is available online. According to information from the Krakow Waterworks' page [4], the water in Krakow is of the same high quality as in other European cities because the quality requirements laid down in Polish regulations are as stringent as EU requirements, and some indicators must meet standards even more rigorous than those laid down by the EU. Treated drinking water is as good as mineral water from bottles, because tap water contains minerals, including calcium and magnesium. The Krakow Waterworks ensures safety of water consumption, guaranteed by daily quality tests of the potable water supplied to Krakow's residents.

\section{THE RESEARCH}

The research was performed in December 2015 in Krakow, during one week. The aim of the research was to assess the variability of ions concentrations during the using of the tap. The influence of the pipe system age was estimated. The samples were taken in two different types of buildings, the old one with the inner water supply installation from the 80 s and in the new one, with installation built in last few years. The new installation is made from copper-zinc pipes with PCV elements. There is no information about material of the old installation probably it is made partly of iron, lead. . All the samples were collected from the same taps. The taps were normally used during the day. The analysed water was supplied from Rudawa Water Treatment Plant. This knowledge makes possible to compare the chemical composition of water analysed by Krakow Waterworks Laboratory(certificate of accreditation No. AB 776) in the Treatment Plant and in the end-user (analysed in this research in certified Hydro-geochemical Laboratory of Hydrogeology and Geology Engineering Department, AGH, certificate of accreditation No. AB 1050). The chemical composition published online for December 2015 see below in table 1 (selected elements according to Krakow Waterworks statement of water quality for 5.12.2015-29.02.2016) [5].

Table 1. The chemical elements of water from Rudawa Water Treatment Plant [5]

\begin{tabular}{|c|c|c|}
\hline Chemical component & $\begin{array}{c}\text { Concentration } \\
(\mathbf{m g} / \mathbf{l})\end{array}$ & $\begin{array}{c}\text { Parametric value } \\
\text { (according to CD 2015/1787) }\end{array}$ \\
\hline Calcium $\left(\mathrm{Ca}^{+2}\right)$ & 110 & - \\
\hline Magnesium $\left(\mathrm{Mg}^{+2}\right)$ & 11.3 & 250 \\
\hline Chlorides $\left(\mathrm{Cl}^{-}\right)$ & 36.3 & 250 \\
\hline Sulphates $\left(\mathrm{SO}_{4}^{-2}\right)$ & 58.0 & 0.2 \\
\hline Iron $\left(\mathrm{Fe}^{+2}\right)$ & $<0.025$ & 2.0 \\
\hline Copper $\left(\mathrm{Cu}^{+2}\right)$ & $<0.003$ & 0.05 \\
\hline Chromium $\left(\mathrm{Cr}^{+3}\right)$ & $<0.002$ & 0.02 \\
\hline Nickel $\left(\mathrm{Ni}^{+2}\right)$ & $<0.0025$ & \\
\hline
\end{tabular}

\subsection{The sampling}

The samples were taken in twotimes of the day and in two different types of building (old and new one). Samples were taken by two qualified operators. To avoid the influence of the tap itself, $1000(\mathrm{ml})$ samples were taken. Thus, the influence of whole installation in the building was analysed [3]. The first sample was collected at the morning at 6 a.m., before the tap in thepremise has been used for other purposes and according to Postawa [6] during the over-night stagnation period no water was drawn from any outlet within the property. When the sample was takenthe tap was fully opened or as open as possible without losing sample. The second sample was taken after the tap was flushed and the third one after 30 minutes stagnation. At the evening was taken one sample (after using the tap all day). 
This sampling scheme make possible toanalyse the concentrations of metals in water properly and is recommended by experts of metal analysis in drinking water [6]. The samples were described in table 2 .

Table 2. Description of samples

\begin{tabular}{|c|c|c|}
\hline Sample & Where was collected? & Description of sample \\
\hline 1 & $\mathrm{~N}$ and $\mathrm{O}$ (new and old building) & Sample was taken at 6 a.m., without prior flushing \\
\hline 2 & $\mathrm{~N}$ and $\mathrm{O}$ (new and old building) & $\begin{array}{l}\text { Sample was taken after the tap was flushed } \\
\text { ( } 3 \text { minutes) }\end{array}$ \\
\hline 3 & $\mathrm{~N}$ and $\mathrm{O}$ (new and old building) & Sample was taken after 30 minutes stagnation \\
\hline 4 & $\mathrm{~N}$ and $\mathrm{O}$ (new and old building) & $\begin{array}{l}\text { Sample was taken after normal using the tap all day } \\
\text { (6 p.m.) }\end{array}$ \\
\hline
\end{tabular}

\subsection{The chemical analyses}

Samples were transported at the day of sampling to the certified Hydrogeochemical Laboratory of Hydrogeology and Geology Engineering Department, AGH and analysed using ICP-OES and ICP-MS methods (according to ISO 11885:2009 [7] and ISO 17294-2:2016 [8]). The physical components ( $\mathrm{pH}$, conductivity) were measured. The concentrations of hydrogen carbonate and chlorides were determined titrimetrically. The analysis contained all the main ions and metals. That made possible to calculate the ion balance. The correctness of chemical composition analysis was verified by calculate analytical error based on the ion balance. According to Polish technical standard PN-89/C-04638/02 [9] and other guidelines [10] analytical error for this water should not exceed $5 \%$. Average errors of the analyses do not exceed this value.

\subsection{The statistical analyses}

In Table 3 have been collated the mean concentration of ions. Statistics were obtained with the exploration procedure using PS IMAGO Software based on IBM SPSS Statistics v.24 http://psimago.pl/. All the box-and-whisker plots were also prepared using IBM SPSS software. Box-whiskers graph presents the quartile distribution. There are values falling within the range between the first and the third quartile, median (the centre line), whiskers (situated about 1,5 the length of the box), outliers and extremes values. The outliers values lies within 1.5-3 the length of the box from lower and top the edge of the box. The extremes values are located over three lengths [11], [12].

Table 3. Mean concentration of selected chemical elements

\begin{tabular}{|l|c|c|c|c|c|c|c|c|c|c|}
\hline Sample & \multicolumn{10}{|c|}{ Mean concentration of chemical elements (mg/l) } \\
\hline & $\mathbf{C a}$ & $\mathbf{M g}$ & $\mathbf{C l}$ & $\mathbf{H C O}_{\mathbf{3}}$ & $\mathbf{S O}_{\mathbf{4}}$ & $\mathbf{F e}$ & $\mathbf{C u}$ & $\mathbf{C r}$ & $\mathbf{N i}$ & $\mathbf{Z n}$ \\
\hline $\mathrm{N} 1$ & 84.0 & 10.34 & 37.62 & 208.4 & 55.32 & 0.022 & 0.020 & $<0.005$ & $<0.001$ & 1.15 \\
\hline $\mathrm{N} 2$ & 70.1 & 9.49 & 31.75 & 191.9 & 43.08 & 0.019 & 0.004 & $<0.005$ & $<0.001$ & 0.19 \\
\hline $\mathrm{N} 3$ & 71.7 & 9.63 & 32.86 & 191.6 & 44.65 & 0.015 & 0.007 & $<0.005$ & $<0.001$ & 0.51 \\
\hline $\mathrm{N} 4$ & 85.3 & 10.48 & 40.67 & 218.6 & 58.10 & 0.010 & 0.007 & $<0.005$ & $<0.001$ & 0.42 \\
\hline mean N & $\mathbf{7 7 . 8}$ & $\mathbf{9 . 9 9}$ & $\mathbf{3 5 . 7 3}$ & $\mathbf{2 0 2 . 6}$ & $\mathbf{5 0 . 2 9}$ & $\mathbf{0 . 0 1 7}$ & $\mathbf{0 . 0 1 0}$ & $<\mathbf{0 . 0 0 5}$ & $<\mathbf{0 . 0 0 1}$ & $\mathbf{0 . 5 7}$ \\
\hline $\mathrm{O} 1$ & 73.0 & 9.70 & 34.06 & 193.5 & 48.49 & 0.037 & 0.005 & $<0.005$ & $<0.001$ & 0.10 \\
\hline
\end{tabular}




\begin{tabular}{|l|l|l|l|l|l|l|l|l|l|l|}
\hline O2 & 68.9 & 9.54 & 32.10 & 187.0 & 44.80 & 0.025 & 0.002 & $<0.005$ & $<0.001$ & 0.01 \\
\hline O3 & 79.1 & 10.23 & 36.36 & 197.8 & 55.06 & 0.023 & 0.004 & $<0.005$ & $<0.001$ & 0.05 \\
\hline O4 & 86.3 & 10.62 & 39.19 & 210.8 & 60.49 & 0.018 & 0.003 & $<0.005$ & $<0.001$ & 0.03 \\
\hline mean O & $\mathbf{7 6 . 8}$ & $\mathbf{1 0 . 0 2}$ & $\mathbf{3 5 . 4 3}$ & $\mathbf{1 9 7 . 3}$ & $\mathbf{5 2 . 2 1}$ & $\mathbf{0 . 0 2 6}$ & $\mathbf{0 . 0 0 4}$ & $<\mathbf{0 . 0 0 5}$ & $<\mathbf{0 . 0 0 1}$ & $\mathbf{0 . 0 5}$ \\
\hline
\end{tabular}

\section{THE RESULTS}

The studies did not show any concentrations higher than the parametric value. This leads to the conclusion that, based on the analysed elements (no microbiological analyses were performed), the quality of water in Krakow is good, but concentrations of chemical components are different at the initial point of water distribution and by the consumers. The results show also, that concentration of metals and related substances are mostly higher in the samples taken without passing the stagnant water in the water system. However all the measured concentrations were lower than the parametric values. The ions concentrations measured in the certified Hydro-geochemical Laboratory of Hydrogeology and Geology Engineering Department, AGH are different than the values presented by Krakow Waterworks (Table 3). It is very important to take into consideration the uncertainty of measure. All certified laboratories declare their own uncertainty. According to certificates of each laboratory ( $\mathrm{AB} 776$ and $\mathrm{AB}$ 1050), presented elements were measured with different methods. That also influences on the results.

At figure 1, on the box-and-whisker plot, were presented differences between $\mathrm{Cu}$ concentration in old $(\mathrm{O})$ and new $(\mathrm{N})$ buildings, in all samples. The highest concentrations were measured in sample N1 (without passing the stagnant water in the water system). All values are also higher than the concentration of $\mathrm{Cu}$ measured in the treatment plant. What is also important, the concentrations in the new building are larger than in the old building. Probably the inner installation in new building is partly made of copper. The parametric value of $\mathrm{Cu}$ concentration in drinking water is 2 (mg/l) (CD 2015/1787).

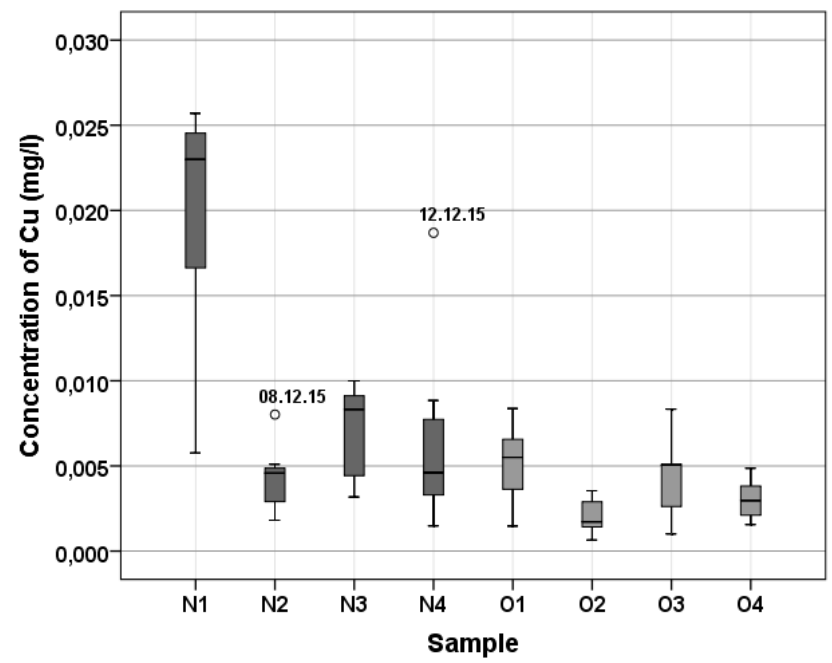

Fig. 1.Concentration of $\mathrm{Cu}(\mathrm{mg} / \mathrm{l})$ in different samples.

At the figure 2 were presented values of $\mathrm{Fe}$ concertation for all samples. The higher concentrations were measured in old building, especially in samples $\mathrm{O} 1$ (without passing the stagnant water in the water system). All values are also higher than the concentration of 
Fe measured in the treatment plant. In this case, probably the old installation is made partly of iron. The parametric value of Fe concentration in drinking water is $0.2(\mathrm{mg} / \mathrm{l})$ (CD 2015/1787).

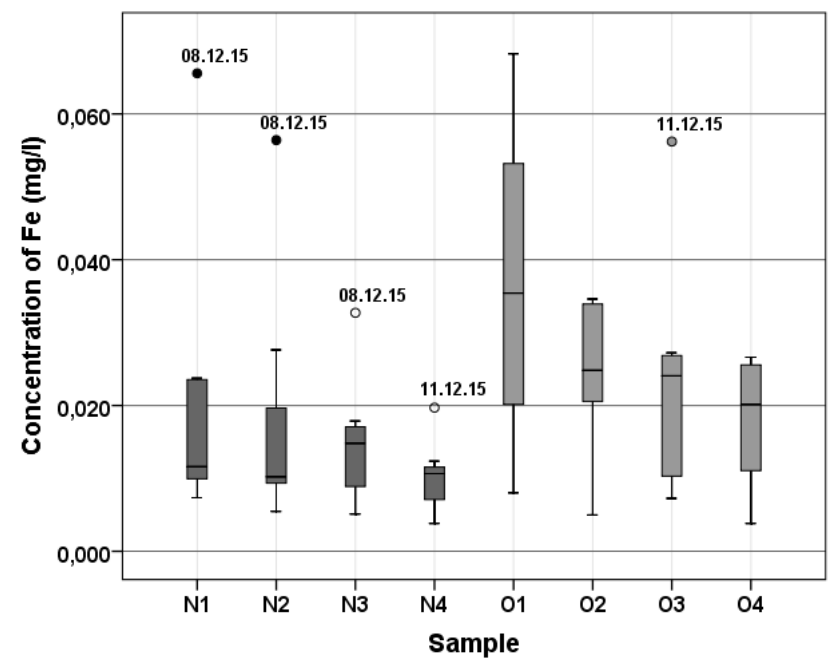

Figure 2. Concentration of $\mathrm{Fe}(\mathrm{mg} / \mathrm{l})$ in different samples.

At the figure 3 were presented concentrations of $\mathrm{Zn}$ for all samples. The higher concentrations were measured in new building, especially in samples N1 (without passing the stagnant water in the pipe-system). The higher concentration could be a result of pipesystem material type. All values are also higher than the concentration of $\mathrm{Zn}$ measured in the old building. The concentration of $\mathrm{Zn}$ in treatment plant is unknown. In (CD 2015/1787) is no parametric value of $\mathrm{Zn}$ concentration in drinking water.

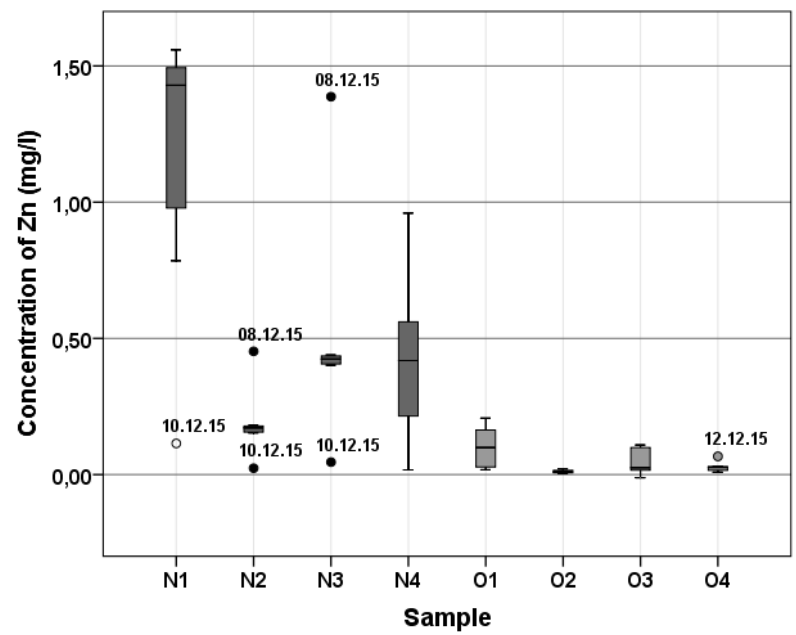

Figure 3. Concentration of $\mathrm{Zn}(\mathrm{mg} / \mathrm{l})$ in different samples. 
At the figure 4 (a) and (b) were presented concentrations of $\mathrm{Ca}$ and $\mathrm{Mg}$ for all samples. The concentrations of two most important cations in water (calcium and magnesium) measured in the certified Hydro-geochemical Laboratory of Hydrogeology and Geology Engineering Department, AGH are lower than the values presented in Krakow Waterworks statement (dotted line). However, the difference is not so high. For example the uncertainty for calcium and also magnesium measure in AGH Laboratory is $11.7 \%$.

a)

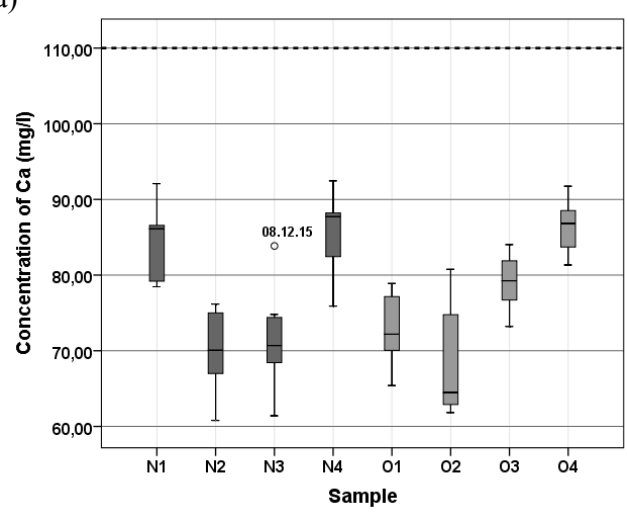

b)

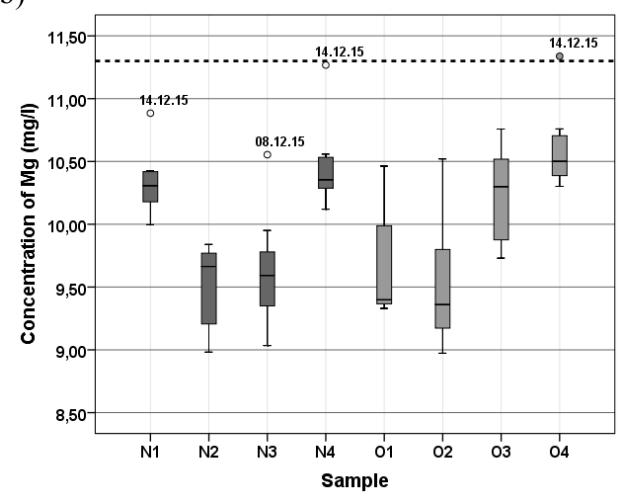

Figure 4. Concentration of (a) $\mathrm{Ca}(\mathrm{mg} / \mathrm{l})$ and (b) $\mathrm{Mg}(\mathrm{mg} / \mathrm{l})$ in different samples, dotted lines present the concentrations measured by Krakow Waterworks Laboratory

\subsection{Conclusions}

The research shows that the quality of water in Krakow is good. The results from certified Hydro-geochemical Laboratory of Hydrogeology and Geology Engineering Department, AGH are different than the concentrations presented in Krakow Waterworks statement. However, the differences are not so high and could be a result of used method or uncertainty. The water in treatment plant but also in the end-user fulfils the requirements of all regulations. The results confirmed the information from Krakow Waterworks about the good quality of water. However, the research shows that the concentrations of selected metals are higher in water collected without flushing the tap.Additionally the material of inner water supply installation influences on the chemical composition of water. But all concentrations of metals are lower than the parametric value include in law regulations [1].The issue is very interesting and consistent with literature, for example this subject was also described in [6],[14] and others publications. The results encourage to expand the research and describe the problem more accurately.

\section{Acknowledgements}

The study was partially supported by AGH-UST11.11.140.797. 


\section{References}

1. Commission Directive (EU) 2015/1787 of 6 October 2015 amending Annexes II and III to Council Directive $98 / 83 / \mathrm{EC}$ on the quality of water intended for human consumption M. Ben Rabha, M.F. Boujmil, M. Saadoun, B. Bessaïs, Eur. Phys. J. Appl. Phys. (to be published) (2015)

2. RMH Regulation of Polish Minister of Health of 13 November 2015 on the scope on quality of water intended for human consumption, Journals of Laws (Dz.U.) No.1989 RMH 2015 (2015)

3. Postawa A., Witczak S., Kmiecik E., Wątor K. Metals and related substances in drinking water in Poland, AGH Publishing 2011(2011)

4. Krakow Waterworks page - http://en.wodociagi.krakow.pl/about-tap-water.html (2017)

5. Krakow Waterworks- statement of water quality for 5.12.2015-29.02.2016 (2015)

6. Postawa A. Best Practice Guide on the Sampling and Monitoring of Metals in Drinking Water, IWA Publishing 2012 (2012)

7. ISO 11885:2009 Water quality - Determination of selected elements by inductively coupled plasma optical emission spectrometry (ICP-OES) (2009)

8. ISO 17294-2:2016-11 Water quality - Determination of selected elements by inductively coupled plasma mass spectrometry (ICP-MS)(2016)

9. PN-89/C-04638/02 Water and waste water - Ions balance of water - Methods of calculation (in Polish) (1989)

10. Witczak S., Kania J. and Kmiecik E. Catalog of selected physical and chemical indicators of groundwater pollution and methods of marking them. Library of Environmental Monitoring. PIOŚ, Warsaw, 2013. (in Polish) (2013)

11. Kmiecik E. Metodological aspects of assessing the chemical status of grounwater, AGH Publishing 2011 (in Polish) (2011)

12. Szczepańska J., Kmiecik E., Drzymała M. Assesment of stability of curative waters chemical composition from ZdrójGłówny in Krzeszowice. Geological Bulletin of the Polish Geological Institute, 63(10/1):830-833 (in Polish) (2009)

13. Wątor K., Mika A. and Postawa A. Influence of installation materials and water stagnation time on the concentrations of selected metals in drinking water (In:) Water supply and water quality, p. 877-889. (2016) 